\title{
Risk factors associated with leptospirosis in swine in state of Pernambuco, Brazil
}

\author{
Fatores de risco associados à leptospirose \\ em suínos no estado de Pernambuco, Brasil
}

\author{
Cleber Vinicius Brito dos Santos ${ }^{1 *}$ (D), Luis Antônio Mathias ${ }^{2}$ (D), Paulo Jedyson da Silva Feitosa ${ }^{3}$ (D), \\ Júnior Mário Baltazar Oliveira ${ }^{3}$ (D) José Wilton Pinheiro Júnior ${ }^{3}$ (D), Daniel Friguglietti Brandespim ${ }^{3}$
}

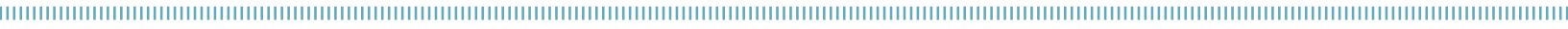

\begin{abstract}
Leptospirosis is a major public health threat, and swine are one of the most important reservoirs and sources of Leptospira infection for man. The aim of this study was to investigate the epidemiological situation of leptospirosis in swine in the state of Pernambuco, Brazil. Blood samples from 265 swine were collected and tested by the microscopic agglutination test (MAT), and an epidemiological form containing questions about animal production characteristics, reproductive management, and sanitary and hygiene aspects of the herd was applied to evaluate infection risk factors. The data were analyzed by means of a logistic regression model. An occurrence of 53.1\% (143/265) of swine positives to Leptospira spp. was observed. The most commons serovars were Icterohaemorrhagiae (39.1\%), Pomona $(25.9 \%)$, and Shermani $(14.0 \%)$. Factors associated with the infection were stagnant water source $(\mathrm{p}=0.034$, odds ratio $-\mathrm{OR}=2.29$; confidence interval of 95\% - 95\%CI 1.06-4.93), farms where the healthy animals are bred with sick ones (OR $=1.69 ; 95 \% \mathrm{CI} 1.04-2.75)$, and the properties with flooded areas $(\mathrm{OR}=1.65 ; 95 \% \mathrm{CI} 1.01-2.68)$. The risk factors found in this study played an important role in the agent dissemination and should be avoided in a way to control the disease in the herds studied.
\end{abstract}

KEYWORDS: diagnosis; epidemiology; Leptospira spp.; pigs; zoonosis.

\begin{abstract}
RESUMO: A leptospirose é um grande problema de saúde pública, e os suínos são um dos mais importantes reservatórios e fonte de infecção por Leptospira para o homem. O objetivo deste estudo foi investigar a situação epidemiológica da leptospirose em suínos no estado de Pernambuco, Brasil. Amostras de sangue de 265 suínos foram coletadas e testadas pelo teste de microaglutinação (MAT), e foi aplicado um questionário epidemiológico contendo perguntas sobre características da produção, manejo reprodutivo e aspectos sanitários e de higiene do rebanho para avaliar fatores de risco de infecçáo. Os dados foram analisados por meio de um modelo de regressão logística. Foi observada ocorrência de 53,1\% (143/265) de suínos positivos para Leptospira spp. Os sorovares mais comuns foram Icterohaemorrhagiae $(39,1 \%)$, Pomona $(25,9 \%)$ e Shermani $(14,0 \%)$. Os fatores associados à infecção foram fonte de água parada $(\mathrm{p}=0,034$; odds ratio $-\mathrm{OR}=2,29$; intervalo de confiança de 95\% - IC95\% 1,06-4,93), fazendas onde animais saudáveis são criados com os doentes $(\mathrm{OR}=1,69$; IC95\% 1,04$2,75)$ e áreas inundadas ( $\mathrm{OR}=1,65$; IC95\% 1,01-2,68). Os fatores de risco encontrados neste estudo desempenharam papel importante na disseminaçáo do agente e devem ser evitados, de forma a controlar a doença nos rebanhos estudados.
\end{abstract}

PALAVRAS-CHAVE: diagnóstico; epidemiologia; Leptospira spp.; porcos; zoonose.

'Instituto de Medicina Social, Universidade do Estado do Rio de Janeiro - Rio de Janeiro (RJ), Brazil

Departamento de Medicina Veterinária Preventiva e Reprodução, Universidade Estadual Paulista “Júlio de Mesquita Filho” - Jaboticabal (SP), Brazil

${ }^{3}$ Departamento de Medicina Veterinária, Universidade Federal Rural de Pernambuco - Recife (PE), Brazil

*Corresponding author: cleber.vini@yahoo.com.br

Received on: 07/11/2017. Accepted on: 07/01/2019 


\section{INTRODUCTION}

Worldwide, leptospirosis is a major public health threat caused by pathogenic spirochetes of the genus Leptospira (BHARTI et al., 2003; LEVETT, 2001). Leptospira spp. is divided into more than 200 serovars, which are related to particular hosts (LEFEBVRE, 2004). One of the most important reservoirs and sources of infection for man is swine. Besides, leptospirosis is also the major pig-associated zoonosis worldwide (NIWETPATHOMWAT et al., 2006; WASIŃSKI; PEJSAK, 2010). Beyond all the public health concern, leptospirosis is a disease of economic signifcance in swine all over the world, because of reproductive losses, such as abortions, stillbirths and weak piglets' birth (BOQVIST et al., 2002; ARENT; ELLIS, 2019).

The disease has been related to both wild and domestic pigs in many countries (KAZAMI et al., 2002; EBANI et al., 2003; GUERRA, 2009). In Brazil, studies were performed to determine the prevalence of leptospirosis and its risk factors in many states, such Alagoas (VALENÇA et al., 2013), São Paulo (AZEVEDO et al., 2006), Rondônia (AGUIAR et al., 2006), and Paraná (DELBEM et al., 2004). The risk of its transmission from pigs to man is additionally increased by the absence of clinical symptoms and the lack of specific symptoms (WASIŃSKI; PEJSAK, 2010).

Despite the fact that Brazil has a National Program for Swine Health (Programa Nacional de Sanidade Suídea PNSS), supervised by a public agency, its implementation is not mandatory for all properties (BRAZIL, 2002; BRAZIL, 2004).

Annually, half million of human leptospirosis cases are estimated to occur worldwide, with the higher incidence in tropical and subtropical areas (WHO, 1999; LEVETT, 2001; BHARTI et al., 2003). In Brazil, leptospirosis is also a major public health problem, with over 9,000 human cases of severe leptospirosis every year (BRAZIL, 2014a).

Studies to improve the knowledge of the risk factors in swine and to better understand its role in the chain of transmission of human leptospirosis are few and especially in the Brazilian northeast. For example, there are none previous studies of leptospirosis in swine in the state of Pernambuco. The purpose of the present study was to investigate the factors that could be associated with Leptospira spp. infection in swine from the state of Pernambuco, Brazil.

\section{MATERIAL AND METHODS}

\section{Sampling}

The sample size was calculated as described by SZKLO; NIETO (2012) using the following parameters: swine population of 421,144 animals in state of Pernambuco, Brazil (IBGE, $2010)$, confidence interval of $95 \%$ (95\%CI), 5\% sampling error and prevalence of $16 \%$, as described by VALENÇA et al. (2013). The minimum sample size, according to the calculation, would be 207 swine.

From February 2014 to January 2015, we collected 265 blood samples from 16 properties, chosen by convenience, and distributed in eight counties: Alagoinha, Belo Jardim, Capoeiras, Garanhuns, São João, Pedra, Venturosa, and São Bento do Una, all in the state of Pernambuco, Brazil (Fig. 1).

The farmers agreed to the sample taking from the swine by a written informed consent. The blood samples $(n=265)$ were collected from the jugular vein, stored, properly identified and sent to the laboratory center. None of the properties vaccinated their animals against leptospirosis, because in this region it is not the practice, and also this vaccination is not mandatory (BRAZIL, 2002; BRAZIL, 2004).

An epidemiological form comprising multiple-choice questions about animal production characteristics, reproductive management, and sanitary and hygiene aspects of the herd was applied in each farm. The epidemiological survey contained 13 possible risk factors for Leptospira spp. infection, as follows: rearing system (intensive, semi-intensive), water source (stagnant/running/both), breeding with other animal species (yes/no), quarantine (yes/no), empty sanitary (yes/no), healthy animals bred with sick animals (yes/no), flooded areas (yes/no), reproductive management (natural/ artificial insemination), origin of animals (farm's own herd/ other farms), presence of other domestic animals (yes/no), presence of wild animals (yes/no), presence of rodents (yes/ no), and rodent control performed (yes/no).

\section{Serology test}

The sera were tested to diagnose using the microscopic agglutination test (MAT). The antigens used were the following reference strains of 24 serovars of Leptospira spp.: Australis, Bratislava, Autumnalis, Butembo, Castellonis, Bataviae, Canicola, Whitc ombi, Cinoptery, Grippotyphosa, Hebdomadis, Copenhageni, Icterohaemorrhagiae, Javanica, Panama, Pomona, Pyrogenes, Hardjo, Wolffi, Shermani, Tarassovi, Andamana, Patoc, and Sentot. The samples that exhibited decrease of free leptospirosis in the range of $50-100 \%$ to the control were exposed to the titration test over a series of geometrical dilutions at the rate of two (TURNER, 1970; COLE et al., 1973). A titer of $\geq 1: 100$ was considered positive (TURNER, 1970). The highest serum dilution capable of agglutinating $50 \%$ or more of Leptospira than the control was considered the endpoint of the reaction (TURNER, 1970; COLE et al., 1973).

\section{Statistical analysis}

A descriptive analysis was used for calculations of the absolute and relative frequencies related to the serologic tests. A univariate analysis was performed, using Pearson's $\chi^{2}$ test or Fisher's 
exact test, when necessary, to evaluate the possible risk factors associated with Leptospira infection. A logistic regression analysis was carried out, using the results of the serological test as a dependent variable. The explanatory variables were those ones that showed statistical significance $<0.20$ in the univariate analysis (HOSMER et al., 2013). This probability was set in order that possible risk factors of the event weren't eliminated from the analysis (HOSMER et al., 2013). The version 23 of the Statistical Package for the Social Sciences for Windows (IBM Corp., 2015) was used to perform the statistical analyses.

\section{Ethical considerations}

The Ethics Committee on Animal Use (Comitê de Ética na Utilização de Animais - CEUA) of the Universidade Federal Rural de Pernambuco (UFRPE) provided scientific and ethical clearance for the present study (license number 044/2013).

\section{RESULTS}

An overall occurrence of 53.1\% (95\%CI 47.2-59.0) for Leptospira spp. infection on swine was observed, with titers varying from 1:100 to 1:1,600 to one or more serovars (Table 1). Considering the number of properties, $93.75 \%$ (15 of 16) of the farms had at least one reacting pig. The occurrence on the positive farms ranged from 6.2 to $93.7 \%$.
Most of the titles (34.9\%) were 1:100. Among the positive samples, $113(79.0 \%)$ reacted just to one serovar, whereas $30(21.0 \%)$ reacted to more than one serovar. Among the positive samples, the highest prevalence was found for the serovars: Icterohaemorrhagiae (39.1\%), Pomona (25.9\%), and Shermani $(14.0 \%)$. The other serovars prevalence varied from 0.0 to $7.7 \%$ (Table 1). The most prevalent serovar related to the numbers of outbreaks was Icterohaemorrhagiae, which was present in $93.7 \%$ of the properties $(15 / 16)$, followed by Shermani and Pomona (Table 2). The serovars Canicola, Grippotyphosa, Icterohaemorrhagiae, and Tarassovi presented the highest titer $(1: 1600)$.

The results of the univariate analysis of the risk factors are presented in Table 3. Logistic regression showed that water source was a risk factor since the risk of infection was 2.29 higher in farms which use stagnant water supply (odds ratio- $\mathrm{OR}=2.29 ; 95 \% \mathrm{CI} 1.06-4.93$ ), as the farms where the healthy animals are bred with seek ones $(\mathrm{OR}=1.69 ; 95 \% \mathrm{CI}$ 1.04-2.75) and the properties with flooded areas $(\mathrm{OR}=1.65$; 95\%CI 1.01-2.68) (Table 3).

\section{DISCUSSION}

This is the first seroepidemiological study to analyze risk factors to Leptospira spp. infection in swine in state of Pernambuco. Swine are one of the most important sources of Leptospira
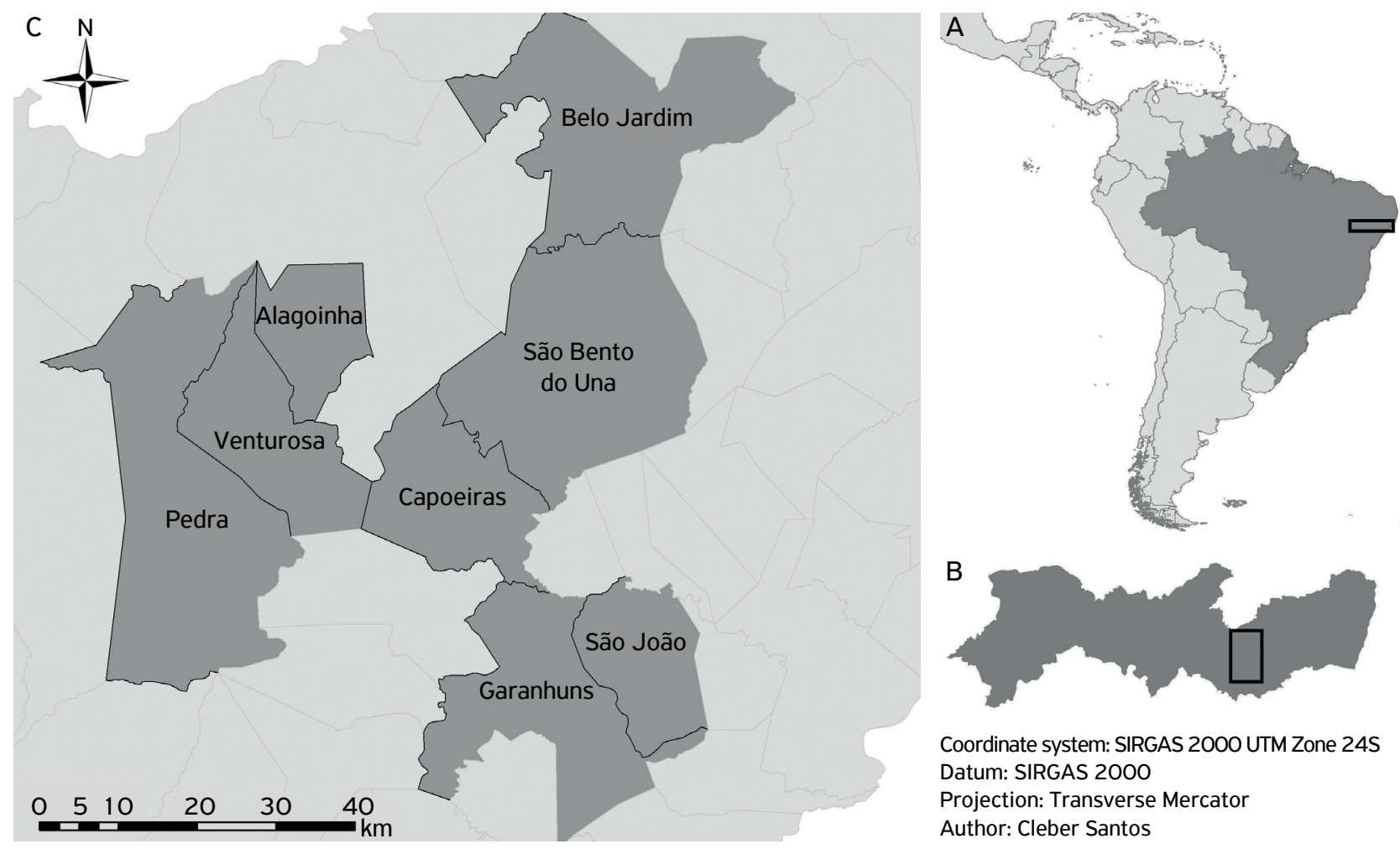

Figure 1. Study area: (A) Northeast Brazil; (B) Pernambuco state; (C) distribution of municipalities in Pernambuco state. 
spp. infection for man and other animals, and since swine in most times do not present clinical symptoms, it is important to discover the occurrence and predominance of Leptospira spp. and their serovars in herds, as well to consider the difference among regions (FAINE et al., 1999; ARENT; ELLIS, 2019). The high seroprevalence is dangerous for both swine herd and man, due that an infected animal can excrete large amounts of leptospires in their urine for long periods (up to one year) (BHARTI et al., 2003).

In this mesoregion, $53.1 \%$ of the samples were positive in the MAT. Researchers in different countries described prevalence ranging from 0.9 to $66.7 \%$ (VAN TIL; DOHOO, 1991; OSAVA et al., 2010; RAMOS et al., 2006; NAITO et al., 2007; WASIŃSKI; PEJSAK, 2010). In Brazil, similar results were described in Pernambuco (45.0\%) (FAVERO et al., 2002), Rio de Janeiro (66.0\%) (RAMOS et al., 2006), and Minas Gerais (47.1\%) (OSAVA et al., 2010). LARSSON et al. (1984) found lower positivity in states such São Paulo (12.0\%), Santa Catarina (10.1\%), and Paraná (8.8\%). This kind of results confirms that leptospirosis in swine occurs frequently, and their prevalence fluctuates depending on the region and risk factors. Such variation in seroprevalence may be due to characteristics of the study site, sampling techniques, analysis methods, environmental conditions, and cut-off used in the interpretation of the results.

The high number of positive properties (93.7\%) suggests that leptospirosis may have widely disseminated in state of Pernambuco. Nevertheless, further studies are necessary to better understand their occurrence, classify it as an enzootic organism, and determine the real impact of infection in the herd and their impact on public health.

Thirty pigs reacted to more than one serovar. It occurs due to cross-reactions or a true multiple infection (MÉRIEN;
ARTHARID, 2005). Serological tests are the most broadly used to diagnose Leptospira spp. (FAINE et al., 1999). The MAT is the standard method for leptospirosis diagnosis, due to his low-cost, and sensibility, but cross-reacting antibodies and vaccination can interfere in the results, especially in low titers, that indicate the past or a chronic infection (FAINE et al., 1999). Therefore, mistakes in the classification of serological status may occur, mainly false-negatives, and the interpretation should be careful (MÉRIEN; ARTHARID, 2005).

In this study, 14 of 24 serovars present in the group of antigens were observed in the swine examined. The higher seroprevalence in the present study was for the serovar Icterohaemorrhagiae. LANGONI et al. (2004) proposed that this positivity occurs in consequence to exposure to rodents,

Table 2. Prevalence of Leptospira spp. serovars per properties in state of Pernambuco.

\begin{tabular}{lcc} 
Serovar & $\begin{array}{c}\text { Proportion of } \\
\text { positive farms }\end{array}$ & $\begin{array}{c}\text { Prevalence } \\
\text { (\%) }\end{array}$ \\
\hline Autumnalis & 3 of 16 & 18.7 \\
\hline Bataviae & 1 of 16 & 6.2 \\
\hline Bratislavia & 6 of 16 & 37.5 \\
\hline Canicola & 1 of 16 & 6.2 \\
\hline Castellonis & 1 of 16 & 6.2 \\
\hline Grippotyphosa & 3 of 16 & 18.7 \\
\hline Icterohaemorrhagiae & 15 of 16 & 93.7 \\
\hline Pomona & 12 of 16 & 75.0 \\
\hline Shermani & 13 of 16 & 81.2 \\
\hline Tarassovi & 7 of 16 & 43.7 \\
\hline Wolffi & 1 of 16 & 6.2 \\
\hline
\end{tabular}

Table 1. Distribution of the serovars of Leptospira spp. in swine from state of Pernambuco.

\begin{tabular}{|c|c|c|c|c|c|c|c|c|c|c|c|c|}
\hline \multirow{3}{*}{ Serovar } & \multicolumn{10}{|c|}{ Incidence of titration found } & \multirow{2}{*}{\multicolumn{2}{|c|}{ Total }} \\
\hline & \multicolumn{2}{|c|}{100} & \multicolumn{2}{|c|}{200} & \multicolumn{2}{|c|}{400} & \multicolumn{2}{|c|}{800} & \multicolumn{2}{|c|}{1600} & & \\
\hline & AF & RF & AF & RF & AF & RF & AF & RF & AF & RF & AF & RF \\
\hline Autumnalis & - & - & 2 & 1.4 & 2 & 1.4 & - & - & - & - & 4 & 2.8 \\
\hline Bataviae & - & - & 1 & 0.7 & 1 & 0.7 & 1 & 0.7 & - & - & 3 & 2.1 \\
\hline Bratislavia & 3 & 2.1 & 3 & 2.1 & - & - & - & - & - & - & 6 & 4.2 \\
\hline Canicola & - & - & - & - & - & - & - & - & 1 & 0.7 & 1 & 0.7 \\
\hline Castellonis & 1 & 0.7 & - & - & - & - & - & - & - & - & 1 & 0.7 \\
\hline Grippotyphosa & - & - & - & - & - & - & 2 & 1.4 & 1 & 0.7 & 3 & 2.1 \\
\hline Icterohaemorrhagiae & 35 & 24.5 & 19 & 13.2 & 1 & 0.7 & - & - & 1 & 0.7 & 56 & 39.1 \\
\hline Pomona & 3 & 2.1 & 12 & 8.4 & 11 & 7.7 & 11 & 7.7 & - & - & 37 & 25.9 \\
\hline Shermani & 7 & 4.9 & 6 & 4.2 & 6 & 4.2 & 1 & 0.7 & - & - & 20 & 14.0 \\
\hline Tarassovi & 1 & 0.7 & 3 & 2.1 & 5 & 3.5 & 1 & 0.7 & 1 & 0.7 & 11 & 7.7 \\
\hline Wolffi & - & - & 1 & 0.7 & - & - & - & - & - & - & 1 & 0.7 \\
\hline Total & 50 & 34.9 & 47 & 32.9 & 26 & 18.2 & 16 & 11.2 & 4 & 2.8 & 143 & 100.0 \\
\hline
\end{tabular}

AF: absolute frequency (n); RF: relative frequency (\%). 
corroborating the study of CHIARELI et al. (2008), because the rodents are the natural hosts of this serovar, and attention should be paid to these numbers, due to this serovar is one of the most associated with severe cases of leptospirosis in humans (BRAZIL, 2014b). Similar results have been found in different parts of the world, as the most prevalent in those countries (VAN TIL; DOHOO, 1991; KAZAMI et al., 2002; BUCHHOLZ et al., 2016). The serovar Castellonis,

Table 3. Analysis of risk factors associated with seroprevalence of Leptospira spp. in swine from the state of Pernambuco, Brazil, 2014.

\begin{tabular}{|c|c|c|c|c|c|}
\hline \multirow{2}{*}{ Variable } & \multirow{2}{*}{$\mathbf{n}$} & Result & \multirow{2}{*}{$P^{*}$} & \multirow{2}{*}{$\begin{array}{l}\text { Logistic regression OR } \\
\qquad(95 \% \mathrm{Cl})\end{array}$} & \multirow{2}{*}{$p^{* *}$} \\
\hline & & Positive & & & \\
\hline \multicolumn{6}{|l|}{ Rearing system } \\
\hline Intensive & 228 & $118(51.7 \%)$ & .963 & & \\
\hline Semi-intensive & 37 & 19 (51.3\%) & & & \\
\hline \multicolumn{6}{|l|}{ Water source } \\
\hline Running & 36 & $14(38.9 \%)$ & & - & \\
\hline Stagnant & 113 & $67(59.3 \%)$ & .063 & $2.29(1.06-4.93)$ & $.034 * * *$ \\
\hline Both & 116 & $56(48.3 \%)$ & & $1.46(0.68-3.14)$ & .325 \\
\hline \multicolumn{6}{|c|}{ Breeding with other animal species ${ }^{1}$} \\
\hline Yes & 225 & $119(52.9 \%)$ & .358 & & \\
\hline No & 40 & $18(45.0 \%)$ & & & \\
\hline \multicolumn{6}{|l|}{ Quarantine } \\
\hline Yes & 79 & 35 (44.3\%) & .117 & & \\
\hline No & 186 & $102(54.8 \%)$ & & $1.52(0.89-2.59)$ & .117 \\
\hline \multicolumn{6}{|c|}{ Healthy animals bred with sick animals } \\
\hline Yes & 140 & $81(57.8 \%)$ & $.034 * * *$ & $1.69(1.04-2.75)$ & $.034 * * *$ \\
\hline No & 125 & $56(44.8 \%)$ & & & \\
\hline \multicolumn{6}{|l|}{ Flooded areas } \\
\hline Yes & 133 & 77 (57.9\%) & $.043^{* * *}$ & $1.65(1.01-2.68)$ & $.043^{* * *}$ \\
\hline No & 132 & $60(45.4 \%)$ & & & \\
\hline \multicolumn{6}{|l|}{ Reproductive management } \\
\hline Natural breeding & 232 & $120(51.7 \%)$ & .982 & & \\
\hline Artificial insemination & 33 & $17(51.5 \%)$ & & & \\
\hline \multicolumn{6}{|l|}{ Origin of animals ${ }^{2}$} \\
\hline Farm's own herd & 192 & $94(48.9 \%)$ & .112 & & \\
\hline Other farms & 61 & $37(60.6 \%)$ & & $1.60(0.89-2.89)$ & .112 \\
\hline \multicolumn{6}{|l|}{ Presence of dogs and cats } \\
\hline Yes & 171 & $94(54.9 \%)$ & .151 & $1.44(0.87-2.40)$ & .151 \\
\hline No & 94 & $43(45.7 \%)$ & & & \\
\hline \multicolumn{6}{|l|}{ Presence of wild animals } \\
\hline Yes & 35 & $17(48.6 \%)$ & .691 & & \\
\hline No & 230 & $120(52.2 \%)$ & & & \\
\hline \multicolumn{6}{|l|}{ Presence of rodents } \\
\hline Yes & 231 & $121(52.4 \%)$ & .563 & & \\
\hline No & 34 & $16(47.0 \%)$ & & & \\
\hline \multicolumn{6}{|l|}{ Rodent control performed } \\
\hline Yes & 52 & $22(42.3 \%)$ & .131 & $1.60(0.86-2.95)$ & .132 \\
\hline No & 213 & $115(54.0 \%)$ & & & \\
\hline
\end{tabular}

${ }^{*} \chi^{2}$ test; **logistic regression model; ***statistically significant at 5\%; OR: odds ratio; $95 \% \mathrm{Cl}$ : confidence interval of $95 \%$; ${ }^{1}$ e.g., horses and cattle; ${ }^{2}$ different base (253). 
also detected in the study, has rodents as the most common hosts (AGUIAR et al., 2006).

In this study, the presence of rodents on the farms was observed in most facilities (87.1\%), as well as the absence of rodents' control (80.4\%). Despite there was no statistical association between control of rodents and Leptospira spp. infection, other studies, such DELBEM et al. (2002), found that farms that do not perform rodents control show higher chances (7.8 times) of infection. Serovar Pomona, the second most prevalent in this study, is host-adapted to swine and it is the main reason for economic losses in swine farms. Due to the evident occurrence of this serovar in the present study, it is suggested that its role in herds should not be overlooked (ARENT; ELLIS, 2019; RAMOS et al., 2006; NAITO et al., 2007).

There was a change in the prevalence pattern of the serovars. Pomona, commonly cited as the predominant all over the world, was substituted by the serovar Icterohaemorrhagiae, corroborating the hypothesis that failures in the rodents control are occurring in the properties and their environments (DELBEM et al., 2002; FAVERO et al., 2002; ARENT; ELLIS, 2019). The serovar Shermani was the third most prevalent in this research, and such prevalence was unexpected, since there are few studies describing this serovar in Brazil, what confirms the heterogeneity of serovars (AZEVEDO et al., 2006). However, neither clinical signs nor reproductive losses associated with this serovar have ever been reported in pigs (DELBEM et al., 2004; AZEVEDO et al., 2006).

The logistic regression showed that water sources with stagnant water $(\mathrm{OR}=2.29 ; 95 \% \mathrm{CI} 1.06-4.93)$ are a risk factor for leptospirosis. Those sources, especially the ones that are non commonly cleaned up, may be used to other animals, mainly the rodents, and, therefore, can be related to their infestation (BOQVIST et al., 2002; MCBRIDE et al., 2005; CHANNON et al., 2006).

Higher prevalence was observed in animals with flooded areas and with access to surface water, which facilitates the transmission of the agent, and consequently it is a risk factor for leptospirosis $(\mathrm{OR}=1.65 ; 95 \% \mathrm{CI} 1.01-2.68)$. Most of risk factors are water-related, a basic need for leptospires surviving (COSTA et al., 2015). Many studies cited water as the most important factor to leptospirosis, and the stagnant water as the main transmission source, due its long period of resistance in that conditions (BARCELLOS; SABROZA, 2001; TRUEBA et al., 2004; MCBRIDE et al., 2005). DOUGLIN et al. (1997) found that people who walk in areas with stagnant water has 25.62 more chances to be positive in leptospirosis diagnosis.

The cohabiting of healthy animals with sick animals in the same site was expected to be a risk factor to leptospirosis $(\mathrm{OR}=1.69$; 95\%CI 1.04-2.75), because this may cause direct or indirect transmission through urine, other body fluids and fomites (FAINE et al., 1999; BOQVIST et al., 2002; MCBRIDE et al., 2005; COSTA et al., 2015). Despite there was no statistical association between wild animals, dogs, cats and other species and leptospirosis, many studies found that significant (BOQVIST et al., 2002; DELBEM et al., 2004; SOTO et al., 2007).

Further studies with the use of polymerase chain reaction (PCR) and culture are necessary to better understand the Leptospira spp. patterns, such as to determine the animals that are eliminating the bacteria and may play a role in the transmission from them to those ones that have only been exposed to the agent. As SOTO et al. (2007) emphasize in their studies, it is fundamental to determine the role of swine in the transmission chain of leptospirosis to humans.

It is suggested that the farms that maintain the healthy animals bred with sick animals change this type of management, as the ones with access to flooded areas in a way to decrease the risk of infection. It is important to pay special attention to the water sources, since the stagnant water was identified as a risk factor to leptospirosis, and we strongly recommend to the farmers who have the water source with stagnant water to change it.

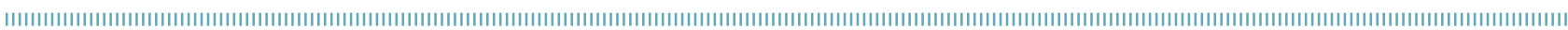
REFERENCES

AGUIAR, D.M.; CAVALCANTE, G.T.; DIB, C.C.; VILLALOBOS, E.M.C.; CUNHA, E.M.S.; LARA, M.C.C.S.H.; RODRIGUEZ, C.A.R.; VASCONCELLOS, S.A.; MORAES, Z.M.; LABRUNA, M.B.; CAMARGO, L.M.A; GENNARI, S.M. Anticorpos contra agentes bacterianos e virais em suínos de agricultura familiar do município de Monte Negro, RO. Arquivos do Instituto Biológico, São Paulo, v.73, n.4, p.415-420, 2006.

ARENT, Z.J.; ELLIS, W.A. Leptospirosis. In: ZIMMERMAN, J.J.; KARRIKER, L.A.; RAMIREZ, A.; SCHWARTZ, K.J.; STEVENSON, G.W.; ZHANG, J. Diseases of swine. 11 . ed. lowa: The lowa State University Press. 2019. p.854-853.
AZEVEDO, S.S.; SOTO, F.R.M.; MORAIS, Z.M.; PINHEIRO, S.R.; VUADEN, E.R.; BATISTA, C.S.A.; SOUZA, G.O.; DELBEM, Á.C.B.; GONÇALES, A.P.; VASCONCELLOS, S.A. Frequency of antileptospires agglutinins in sows from swine herd in the Ibiúna Municipality, State of São Paulo, Brazil. Arquivos do Instituto Biológico, São Paulo, v.73, n.1, p.97-100, 2006.

BARCELLOS, C.; SABROZA P.C. The place behind the case: leptospirosis risks and associated environmental conditions in a flood-related outbreak in Rio de Janeiro. Cadernos de Saúde Pública, v.17, p.S59-S67, 2001. http://dx.doi.org/10.1590/ SO102-311X2001000700014 
BHARTI, A.R.; NALLY, J.E.; RICALDI, J.N.; MATTHIAS, M.A.; DIAZ, M.M.; LOVETT, M.A.; LEVETT, P.N.; GILMAN, R.H.; WILLIG, M.R.; GOTUZZO, E.; VINETZ, J.M.; PERU-UNITED STATES LEPTOSPIROSIS CONSORTIUM. Leptospirosis: a zoonotic disease of global importance. The Lancet. Infectious Diseases, v.3, n.12, p.757-77 1, 2003. https://doi.org/10.1016/S1473-3099(03)00830-2

BOQVIST, S.; CHAU, B.L.; GUNNARSSON, A.; ENGVALL, E.O.; VÅGSHOLM, I; MAGNUSSON, U. Animal-and herd-level risk factors for leptospiral seropositivity among sows in the Mekong delta, Vietnam. Preventive Veterinary Medicine, v.53, n.3, p.233-245, 2002. https://doi.org/10.1016/S0167-5877(01)00263-X

BRAZIL. Ministério da Agricultura, Pecuária e Abastecimento. Secretaria de Defesa Agropecuária. Instrução Normativa no 19 de 15 de fevereiro de 2002. Normas para a certificação de granjas de reprodutores suídeos. Diário Oficial da União, Brasília, 2002.

BRAZIL Ministério da Agricultura, Pecuária e Abastecimento. Secretaria de Defesa Agropecuária. Instrução Normativa n 47 de 18 de junho de 2004. Aprova o Regulamento Técnico do Programa Nacional de Sanidade Suídea — PNSS. Diário Oficial da União, Brasília, 2004.

BRAZIL. Sistema de Informação de Agravos de Notificação. Registro de notificação de casos: Brasil. Brasília: Ministério da Saúde, 2014a.

BRAZIL. Ministério da Saúde. Secretaria de Vigilância em Saúde. Departamento de Vigilância das Doenças Transmissíveis. Leptospirose: diagnóstico e manejo clínico. Brasília: Ministério da Saúde, 2014b.

BUCHHOLZ, A.E.; KATZ, A.R.; GALLOWAY, R.; STODDARD, R.A.; GOLDSTEIN, S.M. Feral swine Leptospira seroprevalence survey in Hawaii, USA, 2007-2009. Zoonoses and Public Health, v.63, n.8, p.584-587, 2016. https://doi.org/10.1111/zph.12266

CHANNON, D.; CHANNON, E.; ROBERTS, T.; HAINES, R. Hotspots: are some areas of sewer network prone to re-infestation by rats (Rattus norvegicus) year after year? Epidemiology \& Infection, v.134, n. 1 , p.41-48, 2006. https://doi.org/10.1017/S0950268805004607

CHIARELI, D.; MOREIRA, E.C.; GUTIÉRREZ, H.O.D.; RODRIGUES, R.O.; MARCELINO, A.P.; MENESES, J.N.C.; ALMEIDA, V.M.A. Freqüência de aglutininas anti-Leptospira interrogans em eqüídeos, em Minas Gerais, 2003 a 2004. Arquivo Brasileiro de Medicina Veterinária e Zootecnia, Belo Horizonte, v.60, n.6, p.1576-1579, 2008. http://dx.doi.org/10.1590/S0102-09352008000600043

COLE, J.R. Jr; SULZER, C.R.; PURSELL, A.R. Improved microtechnique for the leptospiral microscopic agglutination test. Applied Microbiology, v.25, n.6, p.976-980, 1973.

COSTA, F.; HAGAN, J.E.; CALCAGNO, J.; KANE, M.; TORGERSON, P.; MARTINEZ-SILVEIRA, M.S.; KO, A. Global morbidity and mortality of leptospirosis: a systematic review. PLoS Neglected Tropical Diseases, v.9, n.9, p.e0003898, 2015. https://doi. org/10.1371/journal.pntd.0003898

DELBEM, Á.C.B.; FREIRE, R.L.; DA SILVA, C.A.; MÜLLER, E.E.; DIAS, R.A.; NETO, J.S.F.; DE FREITAS, J.C. Fatores de risco associados à soropositividade para leptospirose em matrizes suínas. Ciência Rural, Santa Maria, v.34, n.3, p.847-852, 2004. http://dx.doi. org/10.1590/SO103-84782004000300029
DELBEM, Á.C.B.; FREITAS, J.C.D.; BRACARENSE, A.P.F.; MÜLLER, E.E.; OLIVEIRA, R.C.D. Leptospirosis in slaughtered sows: serological and histopathological investigation. Brazilian Journal of Microbiology, v.33, n.2, p.174-177, 2002. http://dx.doi. org/10.1590/S1517-83822002000200016

DOUGLIN, C.P.; JORDAN, C.; ROCK, R.; HURLEY, A.; LEVETT, P.N. Risk factors for severe leptospirosis in the parish of St. Andrew, Barbados. Emerging Infectious Diseases, v.3, n. 1, p.78-80, 1997. https://doi.org/10.3201/eid0301.970114

EBANI, V.V.; CERRI, D.; POLI, A.; ANDREANI, E. Prevalence of Leptospira and Brucella antibodies in wild boars (Sus scrofa) in Tuscany, Italy. Journal of Wildlife Diseases, v.39, n.3, p.718722, 2003. https://doi.org/10.7589/0090-3558-39.3.718

FAINE, S.; ADLER, B.; BOLIN; PEROLAT P. “Leptospira” and Leptospirosis. Melbourne, Australia: MediSci, 1999.

FAVERO, A.C.M.; PINHEIRO, S.R.; VASCONCELLOS, S.A.; MORAIS, Z.M.; FERREIRA, F.; NETO, J.S.F. Sorovares de leptospiras predominantes em exames sorológicos de bubalinos, ovinos, caprinos, eqüinos, suínos e cães de diversos estados brasileiros. Ciência Rural, Santa Maria, v.32, n.4, p.613-619, 2002. http:// dx.doi.org/10.1590/SO103-84782002000400011

GUERRA, M.A. Leptospirosis. Journal of American Veterinary Medicine Association, v.234, n.4, p.472-478, 2009. https:// doi.org/10.2460/javma.234.4.472

HOSMER, D.W.; LEMESHOW S.; STUDIVART, R.X. Applied logistic regression. New Jersey: John Wiley \& Sons, 2013.

INSTITUTO BRASILEIRO DE GEOGRAFIA E ESTATÍSTICA (IBGE). Sistema IBGE de Recuperação Automática (SIDRA) (2010). Available from: <https://sidra.ibge.gov.br/tabela/3939\#resultado>. Access on: Aug. 122015.

IBM Corp. ., Version 23.0. Armonk, NY: IBM Corp, 2015

KAZAMI, A.; WATANABE, H.; HAYASHI, T.; KOBAYASHI, K.; OGAWA, Y.; YAMAMOTO, K.; ADACHI, Y. Serological survey of leptospirosis in sows with premature birth and stillbirth in Chiba and Gunma prefectures of Japan. Journal of Veterinary Medical Science, v.64, n.8, p.735-737, 2002. https://doi. org/10.1292/jvms.64.735

LANGONI, H.; DA SILVA, A.V.; PEZERICO, S.B.; DE LIMA, V.Y. Anti-leptospirose agglutinins in equine sera, from São Paulo, Goiás, and Mato Grosso do Sul, Brazil, 1996-2001. Journal of Venomous Animals and Toxins Including Tropical Diseases, v.10, n.3, p.207-218, 2004. http://dx.doi.org/10.1590/ S1678-91992004000300003

LARSSON, C.E.; YASUDA, P.H.; SANTA ROSA, C.A.; COSTA, N.O. Leptospirose suína. Inquérito sorológico e bacteriológico em municípios dos estados de São Paulo, do Paraná e de Santa Catarina. Revista da Faculdade de Medicina Veterinária e Zootecnia da Universidade de São Paulo, v.2 1, n. 1, p.43-50, 1984. https:// doi.org/10.11606/issn.23 18-3659.v21i1p43-50

LEFEBVRE, B.L. Spiral-curved organisms V: Leptospira. In: HIRSH, D.C.; MACLACHLAN, N.J.; WALKER, R.L. (Ed.). Veterinary microbiology. 2.ed. Ames, lowa: Wiley-Blackwell, 2004. p. 148-152. 
LEVETT, P.N. Leptospirosis. Clinical Microbiology Revision, v.14, n.2, p.296-326, 2001 https://doi.org/10.1128/ CMR.14.2.296-326.2001

MCBRIDE, A.J.A.; ATHANAZIO, D.A.; REIS, M.G.; KO, A. Leptospirosis. Current Opinion in Infectious Diseases, v. 18, n.5, p.376-86, 2005. https://doi.org/10.1097/01.qco.0000178824.05715.2c

MÉRIEN, F.; ARTHARID, A.B. Leptospirosis a zoonotic under monitoring in New Caledonia and in the Pacific. Preventive Veterinary Medicine, v.200, p.45-50, 2005.

NAITO, M.; SAKODA, Y.; KAMIKAWA, T.; NITTA, Y.; HIROSE, K.; SAKASHITA, M.; KUROKAWA, S.; KIDA, H. Serological evidence of leptospiral infection in pig populations in different districts in Japan. Microbiology and Immunology, v.51, n.6, p.593-599, 2007. https://doi.org/10.1111/j.1348-0421.2007.tb03945.x

NIWETPATHOMWAT, A.; LUENGYOSLUECHAKUL, S.; GEAWDUANGLEK, S. A serological investigation of leptospirosis in sows from central Thailand. Southeast Asian Journal of Tropical Medicine and Public Health, v.37, n.4, p.7 16-719, 2006.

OSAVA, C.F.; SALABERRY, S.R.S.; NASCIMENTO, C.C.N.; LIMARIBEIRO, A.M.C.; MOREIRA, R.Q.; DE CASTRO, J.R.; RIGO, V.H.B. Occurrence of Leptospira spp. antibodies in pigs from different housing systems. Bioscience Journal, v.26, n.2, p.202-207, 2010.

RAMOS, A.C.F.; SOUZA, G.N.; LILENBAUM, W. Influence of leptospirosis on reproductive performance of sows in Brazil. Theriogenology, v.66, n.4, p.1021-1025, 2006. https://doi. org/10.1016/j.theriogenology.2005.08.028

SOTO, F.R.M.; VASCONCELLOS, S.A.; PINHEIRO, S.R.; BERNARSI F.; CAMARGO, S.R. Leptospirose suína. Arquivos do Instituto Biológico, v.74, n.4, p.379-395, 2007.
SZKLO, M.; NIETO, J. Epidemiology. Massachusetts: Jones \& Bartlett Publishers, 2012

TRUEBA, G.; ZAPATA, S.; MADRID, K.; CULLEN, P.; HAAKE, D. Cell aggregation: a mechanism of pathogenic Leptospira to survive in fresh water. International Microbiology, v.7, n. 1, p.35-40, 2004.

TURNER, L.H. Leptospirosis III: maintenance, isolation and demonstration of leptospires. Transactions of the Royal Society of Tropical Medicine and Hygiene, v.64, n.4, p.623-646, 1970. https://doi.org/10.1016/0035-9203(70)90087-8

VALENÇA, R.M.B.; MOTA, R.A.; CASTRO, V.; ANDERLINI, G.A.; PINHEIRO JUNIOR, J.W.; BRANDESPIM, D.F.; GUERRA, M.M.P. Prevalence and risk factors associated with leptospira spp. infection in technified swine farms in the state of Alagoas, Brazil risk factors associated with leptospira spp. in swine farms. Transboundary and Emerging Diseases, v.60, n.1, p.79-86, 2013. https://doi. org/10.1111/j.1865-1682.2012.01320.x

VAN TIL, L.D.; DOHOO, I.R. A serological survey of leptospirosis in Prince Edward Island swine herds and its association with infertility. Canadian Journal of Veterinary Research, v.55, n.4, p.352-355, 1991.

WASINSSKI, B.; PEJSAK, Z. Occurrence of leptospiral infections in swine population in Poland evaluated by ELISA and microscopic agglutination test. Polish Journal of Veterinary Sciences, v.13, n.4, p.695-699, 2010 . https://doi.org/10.2478/ v10181-010-0006-3

WORLD HEALTH ORGANIZATION (WHO). Leptospirosis worldwide. Releve epidemiologique hebdomadaire / Section d'hygiene du Secretariat de la Societe des Nations = Weekly epidemiological record / Health Section of the Secretariat of the League of Nations, v.74, n.29, p.237-242, 1999. 